\title{
Blended-problem based learning: critical thinking skills and information literacy in cell learning

\author{
Vitta Yaumul Hikmawati ${ }^{1,}$ *, Yeni Surya Ningsih ${ }^{2}$ \\ Biology Education Department, Faculty of Teacher Training and Education, Majalengka University, \\ Indonesia \\ ${ }^{1}$ vittayaumul12@gmail.com *, ${ }^{2}$ yenialrasyid@gmail.com \\ * Corresponding author
}

\begin{tabular}{l}
\hline ARTICLE INFO \\
\hline Article history \\
Received $\quad$ October 12, 2019 \\
Revised $\quad$ December 28, 2019 \\
Accepted $\quad$ March 27, 2020 \\
\hline Keyword: \\
Blended-PBL \\
Cell \\
Critical thinking \\
Google classroom \\
Information literacy
\end{tabular}

\begin{abstract}
Critical thinking skills and information literacy are two competencies that students need to have in the millennial era that is loaded with a wide range of types and sources of information. This research was conducted to investigate the effectiveness of blended-problem based learning through Google Classroom application to increase students' critical thinking and information literacy in material about cell. This research was a quasi-experimental with pretest-posttest control group design. Two classes were selected randomly from eight Mathematics and Natural Science (MIPA) grade XI classes in state high school of SMA Negeri 1 Majalengka. The experiment group experienced blended-problem based learning and the control group received a conventional-problem based learning (PBL). Critical thinking skills were measured through a test consisting of essay questions with a reliability of 0.73 . Information literacy competency was measured through a questionnaire using 26 items that had been tested for validity and reliability, resulting in an alpha coefficient of 0.896. Data were analyzed quantitatively using independent t-test and produced p-value of 0.021 and 0.018 for critical thinking skills and information literacy respectively. This shows that statistically there are significant differences in students' critical thinking skills and information literacy between blended-PBL and conventional-PBL. This research indicates that the blendedPBL strategy can be implemented as a learning strategy, especially in Biology to prepare students for the $21^{\text {st }}$ century challenges.
\end{abstract}

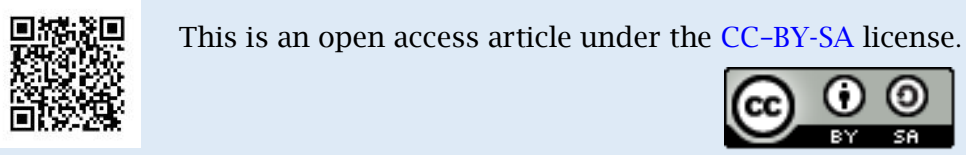

\section{Introduction}

In the era of the Industrial revolution, Google and any other search engine have become a dependable main source of information for the students to fill their need for any information. The ease of accessing information offered by the internet is both an opportunity and challenge for education practitioners in facilitating the students to develop their critical thinking skills and information literacy (IL) along with their information technology (IT) skill (Kong, 2014). 
The urge of mastering IL is growing rapidly, even though the concept itself was defined years before. According to Zurkowski (1974), IL is the use of any information device in order to solve individual problems. The way of collecting information is shifted due to the rapid development of IT as stated by Schiffl (2018), the problems will be faced by students in the modern era are not the accessibility to information but management and critical evaluation against false, outdated and contradicting information. The development of IT generates the speed and convenience in accessing information, which will bring out advantages only if the students are competent in IL.

Information literacy is closely related to the ability of seeking and discovering information's effectively, evaluating, comparing, sorting, analyzing, managing, using and delivering information's ethically to others in a learning community (Association of College and Research Libraries, 2000). The definition of IL by Association of College and Research Libraries (ACRL) (2000) as a set of integrated abilities encompassing the reflective discovery of information, the understanding of how information is produced a value and the use of information in creating new knowledge and participate ethically in communities of learning. American Association of School Librarians (AASL) and Association for Educational Communications and Technology (AECT) (1998) has established the standards of IL which then developed into 3 categories, 9 standards, and 29 indicators. The standard of IL describes a series of integrated competencies students must be mastered to be categorized as a person with IL.

Critical thinking is a part of cognitive skill which consists of interpretation, analysis, evaluation, inference, explanation, and self-regulation (Facione, 2011). Literature reviews show that the implementation of Blended-PBL gives out a significant impact to critical thinking and learning outcomes (Derby \& Williams, 2010).

Preliminary studies in SMA Negeri 1 Majalengka show some facts related to the use of IT. First, the school has sufficient computer laboratory in quality and quantity. Second, assignments given by teachers, specially Biology teacher give students opportunities to explore and optimize the benefit of internet. Third, the student's skill in choosing and sorting internet-based information has not yet become teacher's attention. The interviews on some randomly chosen students and Biology teacher revealed some of the facts. First, students were not familiar with the Biology problems which demand High Order Thinking skill. Second, Biology teaching has only focused on conceptual assignment such as remembering, identifying, ordering, and re-explaining without implementing any analyzing ability on specific attributes of a concept. These facts become the fundamental to combine the technology application with certain teaching steps.

PBL model has been reported to have pre-eminence, particularly in changing the old paradigm of learning focus. The old paradigm describes that learning is focused on passive absorption of information while PBL is focused on active seeking of information (Leibiger, 2011), which emphasized in constructive perspective. On the other side, Blended learning need a teaching model which guarantee the effectivity of online learning environment (Kazu \& Demirkol, 2014).

Online learning has offered an open access for a constant and time-limitless learning which traditional offline classes has not. Even with its time and space flexibility, online learning has limit in interaction. But the same problems are also found in offline learning. The best solution for these problems is by online-offline learning collaboration (Yilmaz \& Orhan, 2010).

Google Classroom with its multiplatform can be a solution to eliminate classical learning limit. Google Classroom has a beneficial potential to stimulate ideas on collaborating face-toface learning model with online learning model, based on Kwan and Yunus (2015), "Collaborative learning increases students results and extends one's level of understanding". Google Classroom has become a determiner between this research and former research conducted by Triyanto, Prayitno, and Probosari (2014) with Moodle online learning.

Blended-PBL is a combination of Blended learning strategy with Problem Based Learning (PBL) model as a pedagogic model. The steps of PBL become the basic references for face-to-face learning which 
preceded by online learning using platform such as Google Classroom. The reason why PBL model is combined with Blended learning is based on former research report on how PBL is relevant for teaching IL skill as a naturally integrated with the assignment (Wenger, 2014). The assignment needed in PBL positively develop High Order Thinking skill such as critical thinking skill (Triyanto et al., 2014).

We need to consider the characteristic of Biology teaching material in order to make this application of Blended-PBL effective. Cell, as one of the teaching materials in Biology has relatable characteristics with the students daily basic and considered as the appropriate material to be implemented as the stimulus in authentic PBL learning.

As Blended-PBL has a big potention to increase student's ability in IL and critical thinking skill, so this research has particular objective to be one of alternative solution in accommodating those skills with cell as learning material.

\section{Method}

Quasi experiment with pretestposttest control group design was applied in this research. The subject of this research was the students of math and science program grade XI in SMA Negeri 1 Majalengka, with cluster random sampling for its sampling method. One class consisting 37 students was chosen as control group and one class consisting 36 students as experiment group.

Research was conducted on JulySeptember 2019. Pretest was given to students before implementing the PBL learning. Experiment group was then given the Blended-PBL model in learning, while control group was given classical PBL learning or complete face-to-face model. Blended-PBL was implemented in experiment group using a combination of online learning (Google Classroom) and face-to-face learning.

Learning activity was held five times in total, consist of two online activities at the beginning and three offline activities. Activities were including formulating problems, constructing hypothesis and gathering relevant information.

Posttest was given to each group after learning implementation to measure students IL and critical thinking skill. Results of both pretest and posttest of each group were calculated to get the average score and then compared using statistical analysis.

Test technic developed by Facione (2011) was applied to measure students' IL and critical thinking skill referred to the definition of critical thinking skill as a part of cognitive skill which consist of interpretation, analysis, evaluation, inference, explanation and self-regulation. Questionnaire and guided interview were chosen as non-test technic. Questionnaire was applied to measure students IL, while guided interview was applied to gather students responds on learning model. Variables of IL were measured using marking standard developed by AASL and AECT (1998): Information literacy standards for students learning. Three categories were setted as stepping points for the construction of questions item stated as three closed statement using Likert scales. These three categories including IL, independent learning and social responsibility.

Test instruments were examined to measure critical thinking skill to reveal its validity and reliability. Non-test instruments were examined for its validity using expert judgement done by two lecturers. Fifteen essay questions were examined and twelve questions were confirmed as valid. Reliability score for critical thinking skill questions was 0.63 and considered as high.

Data was analyzed descriptively using Microsoft Office Excel 2010. Discrimination test was chosen to examine hypothesis using SPSS ver. 20. Independent samples t-test were used to determine the differences between two conditions, before and after model implementation for uncoupled groups (Riadi, 2016).

\section{Results and Discussion}

This research began with an introduction to Google Classroom and Blended-PBL model to experiment group, as well as PBL model to control group. The objective of this introduction was to let students familiar with the objective and syntax of PBL in order to minimize bias within research.

Pretest was held before implementation of both models to reveal student's prior knowledge in each treatment group. Preliminary result in critical thinking skill showed that the rate 
of student's achievement in control group and experiment group were 47.4 and 50 consecutively.

Students were faced with problems related to "Cell" through Google Classroom, consisting deficiency of cell chemically construction components, deficiency of cells structures and functions and its health impact. Problems were served in articles, delivered to students through "material" feature. Students were given 15 minutes to read and comprehend the problems. After 15 minutes, students were led to formulate problems, construct hypothesis and gather relevant and relatable information through "assignment" feature. Some questions were given to reflect students comprehension related to the problems, identification of information needed to gain solutions and strategies to gain solution according to the articles, including: "What do you know?", What do you need to know?" and "What will you do to know?".

After gathering relevant information, students were asked to send the links of articles/e-book/video (if information were taken from internet) or write down author name, year of issued, title and publisher (if information were printed in books or other media). Results of sorting relevant information related to the problems submitted by the students through Google Classroom showed that this activity has optimally done by students with minimal 5 sources of information. Space and time flexibility for online learning has given students more freedom to seek proper information to gain solution.

Post test result showed the achievement of average score for students critical thinking skill has increased compared to pre-test, which were 69 for control group and 72 for experiment group. This results also showed that experiment group achieved higher score than control group in every indicator.

Results of data normality test using Saphiro-Wilk as shown in Table 1, p-values for control group was 0.651 and 0.429 for experiment group. Since the p-value $>0.05$ for both groups, the distribution was considered normal. Results for homogeneity test using Levene's method has shown p-value for 0.256 ( $\mathrm{sig}>0.05$ ). it means there were similarities of variants between two groups or simply said both groups were homogeny. To reveal the statistical differences on both groups, an independent test was done to test the hypothesis.

Table 1. Normality test with Shapiro-Wilk

\begin{tabular}{llcc}
\hline \multicolumn{1}{c}{ Group } & \multicolumn{3}{c}{ Saphiro-Wilk } \\
& Statistic & df & Sig. \\
\hline Control & 0.978 & 37 & 0.651 \\
Experiment & 0.970 & 36 & 0.429 \\
\hline
\end{tabular}

Independent t-test output (Table 2) showed $\mathrm{p}$ value for $0.021 \quad(<0.05)$ and statistically concluded there were significant differences between both groups. Mean difference between both groups was -5.051. the negative value indicated that first group (control group) had lower mean value than experiment group. This discovery ii consistent with Derby and Williams (2010) that proved the positive result of Blended-PBL implementation gave out significant impact to learning and critical thinking skill outcomes.

Table 2. Hypothesis testing with independent t-test

\begin{tabular}{clccc}
\hline t & df & $\begin{array}{c}\text { Sig.(2- } \\
\text { tailed) }\end{array}$ & $\begin{array}{c}\text { Mean } \\
\text { Differ } \\
\text { ence }\end{array}$ & $\begin{array}{c}\text { Std. } \\
\text { Error } \\
\text { Differen } \\
\text { ce }\end{array}$ \\
\hline-2.35 & 71 & 0.21 & -5.051 & 2.145 \\
-2.36 & 68.85 & 0.21 & -5.051 & 2.139 \\
\hline
\end{tabular}

Improvement of students critical thinking skill on both groups were categorized as medium based on N-gain categories. Though the average scores on both groups improved in the same gain category, but the achievements of students critical thinking skill through PBL were different in each indicator.

Graphic in Figure 1 shows the critical thinking skill indicators measured in this research have improved. It is shown by the comparation between pre-test and posttest result. Both data show the same pattern between the highest and lowest scores in whether pre-test or post-test. The highest score was gained in interpretation and the lowest was gained in explanation. Both indicators gained their highest average scores after implementation of PBL model compared to other indicators. But this result did not show a significant difference between pre-test and post-test. Pre-test average score was 73 for both groups, while post-test average score was 87 for experiment group and 85 for control group. 


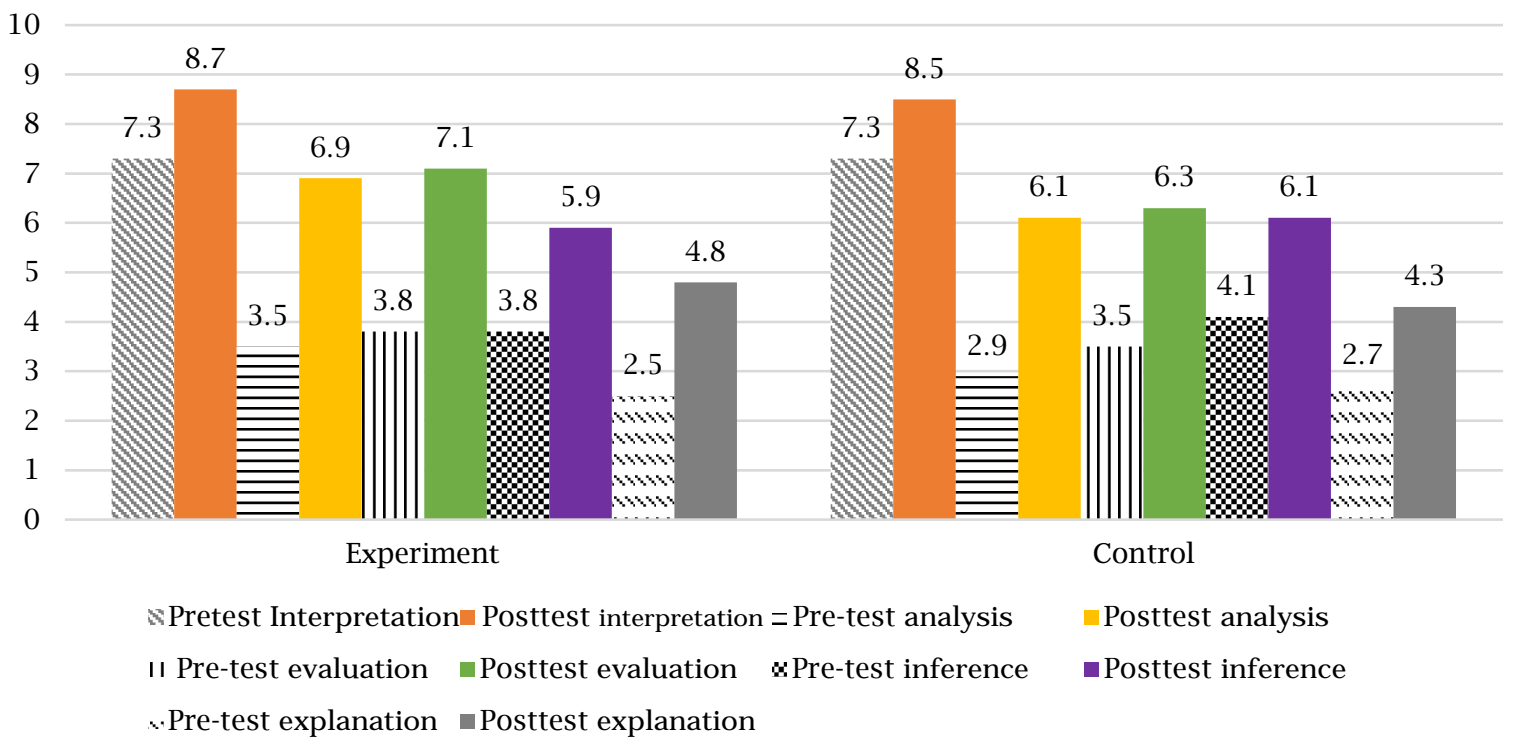

Figure 1.Increased critical thinking skills on every indicator

Among 3 sub indicators of interpretation (classify, generalize and explain the purposes), the lowest score gained in explaining the purposes. In this sub indicator, students were facing an article with illustrations to describe morphological condition of some healthy and unhealthy corn leaves. Questions were given to lead students to explain the description of chlorosis in leaves according to the observed characters. Most of the students tended to focus on the symptoms which easily observed such as colors and shape of the leaves while leaving other details unobserved.

The low score for this sub indicator was also caused by most of students (70\%) only focus on pointing which leaves undergo chlorosis without any explanation about chlorosis according to the observed morphological features.

For this explanation indicator, students were asked to determine the $\beta$ cells' structure and functions deficiency in diabetic mellitus and consider the cause of this deficiency. Even though students average score was low in these indicators, but both groups were improving after PBL implementation. This result is relevant with Kazu and Demirkol (2014) that reported the implementation of PBL both in Blended and classical model has improved students learning outcomes significantly.

The discovery of this research indicates that PBL model whether conventional or blended-PBL significantly improved critical thinking skill of senior high school students with "Cells" as the subject. Students critical thinking skill was improved in every aspect tested: interpretation, analysis, evaluation, and significantly in inference and explanation. This is relevant with Dogan (2017) statement, a series of investigation within PBL was able to develop High Order Thinking skill.

For analysis ability, students were asked to identify inferential connection between healthy plants concepts which described verbally and its relation with symptoms of elements deficiency in plants based on prepared representative pictures. Students answers in control group were focusing more on inherent connection between available data and information, so they just gave a short and compact answers without mentioning other factors that might affect in nutrient deficiency of plants. A different finding was revealed in experiment group, which answers were covering a broader aspect than just focusing on available data and information within questions.

Reviewing the improvement of critical thinking skill, the result of this research is similar to Triyanto et al. (2014), evaluation indicator has the highest improvement. Control group has gained the highest score in analysis indicator, while the experiment group gained the highest score in evaluation. Students of experiment group tented to have the ability to access the credibility of data or statements faster than students of control group. 
This result was also found in class action research conducted by Triyanto et al. (2014), with the highest score gained in evaluation. This research was also confirmed the result of Triyanto et al. (2014), that the least improvement was in inference indicator.

Students answers recapitulation in inference showed 3 group of answers. First, group of students with correct answer. Students who answered correctly in inference question were able to identify the characters of healthy leaves based on observed morphological features, sorting beneficial information in order to draw logic conclusion on the relationship between deficiency of cell chemical components and the morphological appearance. Second, students who were able to identify and sort information related to morphological features of healthy and unhealthy leaves, but the conclusions were drawn incompletely. Third, a group of students who were able to identify and sort information but the conclusion was irrelevant with the information or even did not draw a conclusion at all.

$$
\text { Potency of Blended-PBL }
$$

implementation was manifested in students learning habits which stressed on self-learning. The concept of self-learning which is main concern of PBL, distinguish it from other active-learning model such as cooperative and discovery-learning. The self-learning in PBL was started with information identification process which related to the problems faced by the students. Later on students also need to identify, decide and set the objective of additional information necessity to solve their problems and how to evaluate it (Vesisenaho et al., 2010).

The application of Google Classroom eased the students to seek information in form of e-book, articles or video. Online meeting through Google Classroom facilitate students to do self-learning, control their experience in constructing knowledge by gathering relevant information. Questions given by teachers to direct the seeking information process. Problems delivered by teachers through online have an important role in generating students enthusiastic and curiosity, also develop their critical thinking skill.

Similar with the result of this research, Pinheiro (2012) was once reported that collaborative learning has improved students learning outcomes and developed their knowledge from lower level up to higher comprehensive level. Saliba, Mussleman, Fernandes, and Bendriss (2017) affirmed that investigation activities to find solution has developed student's cognitive ability to a higher level.

The advantage of PBL in developing students cognitive ability has also been stated by Dogan (2017), PBL help students to develop their metacognitive ability such as critical thinking skill, solving problems and communication skill.

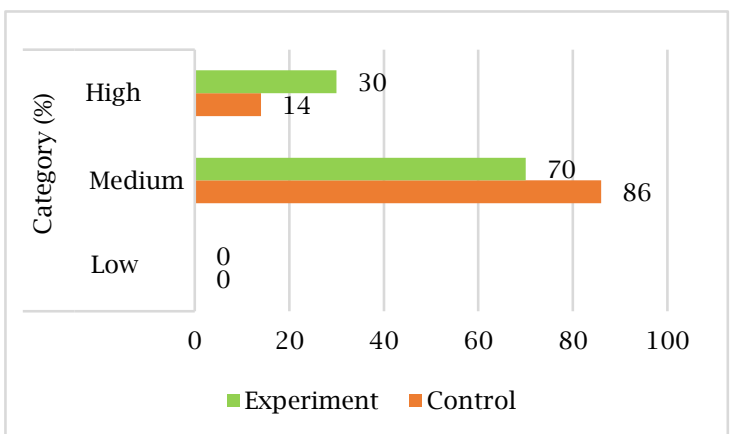

Figure 2.Percentage of student information literacy categories

Figure 2 shows percentage of students with IL in high category were found more in experiment group than in control group. Figure 2 also illustrates the same categorizing pattern between both groups. Most students whether in control group or experiment group have medium improvement. Least students within both groups were categorized high.

Comparison of students IL in both groups is served in Figure 3. An interesting fact shown by Figure 3 is that average result of students within experiment group is higher than control group in IL and independent learning. While the average score of students in control group is higher than those in experiment group in social responsibility. Independency in seeking relevant information, space and time flexibility in accessing limitless information offered by Google Classroom enable the students in experiment group to achieve a higher IL than those in control group.

IL categories consist of accessing information efficiently and effectively and evaluating information completely and critically. Online seeking information activity by students in experiment group during online learning made them work hard to seek information and construct the 
knowledge. A series of processes in Blended-PBL gave some opportunities to the students to develop their comprehend through investigation. IL is a part of natural and integrated investigation activity in PBL (Wenger, 2014).

The negative side of the highly independent students in learning shown by this research was the lack of social responsibility. As once showed by Back et al. (2014) in his research, Blended-PBL is superior than face-to-face PBL because the arrangement of Blended-PBL is supporting independent learning. The lack of social responsibility in experiment group was supported by the field observation result.

Observation result for discussion process in face-to-face PBL showed that during the group work the members participation was imbalance. Discussion process was only dominated by one or two students out of 4 members. The low participation in experiment group showed that group investigation did not guarantee an active participation for the whole group. The observation result showed that the lack of social responsibility in experiment group is relevant to Back et al. (2014) who stated that one of the weakness in online PBL was social isolation.

The time limitation in control group students to seek information and decide the solution made them tend to split out the assignment with the group members. Students coordination in splitting out the assignment was not followed by information collaboration and reobservation. So, the knowledge was not constructed completely. The split-out assignment without sharing information was like eliminate the essential step of group discussion. As Khoiriyah, Roberts, Jorm, and Van der Vleuten (2015) affirmed that most of the time, students passed the essential step of investigation process in PBL, which then lessen the quality of PBL and cause the failure of teachers' expectation on learning outcomes through PBL.

Based on the result of this research, the success of Blended-PBL implementation must consider some important things. First, the will of the students to participate actively in internetbased learning. Second, the chosen subject to be discussed must be updated, interesting and stimulating student's curiosity to seek for more information. Third, questions given by teachers to direct the online discussion should be a productive type of questions which able to stimulate students to seek information.

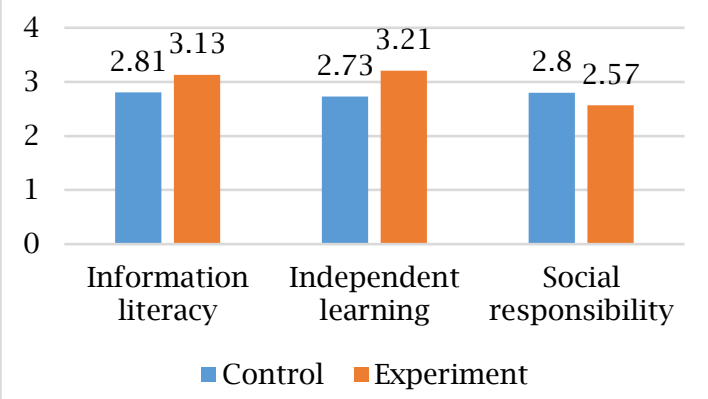

Figure 3.Comparison of students' average information literacy scores in each category

This research has some limitations because of the absent of control in accessing information. This condition enables students to share the links of references among themselves. Some students got caught sending the similar links of references. This similarity might be happened by accident or they purposely share the same links. This condition will disturb the development of students IL.

Regardless the weakness of this research, the implementation of BlendedPBL as a learning model has proven to be effective in developing students critical thinking skill and IL. The result of this research may be used as a basic in choosing learning strategy to develop critical thinking skill.

\section{Conclusion}

Effectivity of Blended-PBL in the improvement of critical thinking skill and IL has manifested in students learning habit, particularly in the exploration to gain information of what students know, how they gain the information they need and how they plan to manage the strategy to implement the process of seeking information independently. Time and space flexibility are the determinator between Blended-PBL and face-to-face PBL which resulting different improvement for every critical thinking indicators and developing students IL. The ease of accessibility and connectivity of Google Classroom gave the limitless exploration to the students in order to help them develop their IL based on "Cell" as the chosen subject. 


\section{Acknowledgment}

This research was carried out with financial support from the Ministry of Research, Technology, and Higher Education, which was technically facilitated by the Center for Research and Community Service (P3M) Majalengka University. Thank you to Biology teacher SMAN 1 Majalengka for their cooperation during the research, as well as all students of SMAN 1 Majalengka students for their participation in this research.

\section{References}

American Association of School Librarians, \& Association for Educational Communications and Technology. (1998). Information literacy standards for student learning: Standards and indicators. Retrieved from https://www.ala.org/ala/aasl /aaslproftools/informationpower/I nformationLiteracyStandards_final. pdf

Association of College and Research Libraries. (2000). Information literacy competency standards for higher education. Retrieved from http://www.ala.org/acrl/standards /informationliteracycompetency

Back, D. A., Haberstroh, N., Antolic, A., Sostmann, K., Schmidmaier, G., \& Hoff, E. (2014). Blended learning approach improves teaching in a problem-based learning environment in orthopedics - a pilot study. BMC Medical Education, 14(1), 17. https://doi.org/10.1186/ 1472-6920-14-17

Derby, C., \& Williams, F. (2010). The impact of problem based Learning, blended-problem based learning, and traditional lecture on student's academic achievement in education. In J. Sanchez \& K. Zhang (Eds.), E-Learn: World Conference on E-Learning in Corporate, Government, Healthcare, and Higher Education (pp. 50-55). Retrieved from https://www.learn techlib.org/p/35509/

Dogan, N. (2017). Blending problem based learning and history of science approaches to enhance views about scientific inquiry: New wine in an old bottle. Journal of Education and
Training Studies, 5(10), 99-112. https://doi.org/10.11114/jets.v5i1 0.2646

Facione, P. A. (2011). Critical thinking: what it is and why it counts. Retrieved from https://www.student.uwa.edu .au/__data/assets/pdf_file/0003/1 922502/Critical-Thinking-What-itis-and-why-it-counts.pdf

Kazu, I. Y., \& Demirkol, M. (2014). Effect of blended learning environment model on high school students' academic achievement. TOJET: The Turkish Online Journal of Educational Technology, 13(1), 7887. Retrieved from https://files. eric.ed.gov/fulltext/EJ1018177.pdf

Khoiriyah, U., Roberts, C., Jorm, C., \& Van der Vleuten, C. P. M. (2015). Enhancing students' learning in problem based learning: validation of a self-assessment scale for active learning and critical thinking. $B M C$ Medical Education, 15(1), 140. https://doi.org/10.1186/s12909015-0422-2

Kong, S. C. (2014). Developing information literacy and critical thinking skills through domain knowledge learning in digital classrooms: An experience of practicing flipped classroom strategy. Computers \& Education, 78, 160-173. https://doi.org/10.1016/j.comped u.2014.05.009

Kwan, L. S. L., \& Yunus, M. M. (2015). Group participation and interaction in ESL wiki collaborative writing among malaysian gifted students. Asian Social Science, 11(2), 59-68. https://doi.org/10.5539/ass.v11n2 p59

Leibiger, C. A. (2011). "Google reigns triumphant"?: stemming the tide of googlitis via collaborative, situated information literacy instruction. Journal Behavioral \& Social Sciences Librarian, 30(4), 187-222. https://doi.org/10.1080/01639269 .2011 .628886

Pinheiro, P. A. (2012). Collaborative writing by means of digital tools: resignifying textual production in the school context. International Research Journal of Arts and Social Sciences, 1(1), 8-21. Retrieved from https://www.interesjournals.org/a 
rticles/collaborative-writing-bymeans-of-digital-tools-resignifyingtextual-production-in-the-schoolcontext.pdf

Riadi, E. (2016). Statistika penelitian: Analisis manual dan IBM SPSS. Yogyakarta: Andi offset.

Saliba, R., Mussleman, P., Fernandes, M., \& Bendriss, R. (2017). Promoting information literacy of pre-medical students through project-based learning: a pilot study. International Journal of Education and Literacy Studies, 5(4), 1-15. https://doi.org/10.7575/aiac.ijels. v.5n.4p.1

Schiffl, I. (2018). How information literate are junior and senior class biology students? Research in Science Education, 50, 773-789. https://doi.org/10.1007/s11165018-9710-2

Triyanto, S. A., Prayitno, B. A., \& Probosari, R. M. (2014). Penerapan model pembelajaran blended-problem solving melalui aplikasi moodle untuk meningkatkan kemampuan berpikir kritis siswa kelas X-1 SMAN 3 Surakarta tahun pelajaran 2012/2013. BIO-PEDAGOGI: Jurnal Pembelajaran Biologi, 3(1), 99-108.
Retrieved from https://jurnal.uns. ac.id/pdg/article/view/5326

Vesisenaho, M., Valtonen, T., Kukkonen, J., Havu-Nuutinen, S., Hartikainen, A., \& Karkkainen, S. (2010). Blended learning with everyday technologies to activate students'collaborative learning. Science Education International, 21(4), 272-283. Retrieved from https://files.eric.ed.gov/fulltext/EJ 907048.pdf

Wenger, K. (2014). Problem-Based Learning and information literacy: A natural partnership. Pennsylvania Libraries: Research \& Practice, 2(2), 142-154. https://doi.org/10.5195/ PALRAP.2014.61

Yilmaz, M. B., \& Orhan, F. (2010). Preserviceenglish teachers in blended learning environment in respect to their learning approaches. TOJET: The Turkish Online Journal of Educational Technology, 9(1), 157164. Retrieved from https://files. eric.ed.gov/fulltext/EJ875779.pdf

Zurkowski, P. G. (1974). The information service environment relationships and priorities. Related paper no. 5. Retrieved from https://eric.ed. gov/?id=ED100391 